\title{
Mitigasi Bencana Akibat Kegagalan Struktur
}

\author{
Susy Srihandayani \\ Program Studi Teknik Sipil, Sekolah Tinggi Teknologi Dumai \\ Jl. Utama Karya Bukit Batrem II \\ Email: gadisoil79@gmail.com
}

\begin{abstract}
ABSTRAK
Banyak terjadi kerugian, kerusakan Bangunan di daerah yang mempunyai lapisan tanah lunak akibat kegagalan pondasi. Selain itu pondasi di tanah lunak umumnya memerlukan konstruksi yang relatif sangat mahal. Bencana dapat juga terjadi karena faktor alam dan bisa juga terjadi akibat kegagalan teknologi. Kegagalan bangunan telah di definisikan oleh UU RI No.2 Tahun 2007 dan PP No. 29 Tahun 2000. Dilihat dari segi ketekniksipilan, Kegagalan bangunan terjadi apabila bangunan tersebut kurang/ tidak memiliki unsur-unsur kekakuan, kekuatan, stabilitas, dan keamanan, sebagaimana yang dipersyaratkan dalam peraturan/ketentuan yang berlaku terhadap bangunan tersebut. Kegagalan dalam hal ini, dapat dibagi atas, Kegagalan ringan, kegagalan sedang dan kegagalan berat. Kegagalan dapat diawali dari kegagalan pada tahap penyelidikan/ survey, perancangan/ disain, konstruksi (pelaksanaan) dan tahap perawatan (Maintenance). Guna menentukan kegagalan dapat dipakai tolak ukur bahwa semua bangunan harus direncanakan, di bangun, di pelihara mengikuti peraturan nasional dan peraturan daerah serta berbagai standar dari asosiasi asosiasi jasa konstruksi. Selain itu khusus untuk mendisain sebuah pondasi harus menyesuaikan dengan hasil penyelidikan tanah di lapangan.
\end{abstract}

Kata kunci: Bencana, Tanah Lunak, Kegagalan Pondasi.

There are many losses, damage to buildings in areas that have soft soil layers due to foundation failure. In addition, foundations on soft soil generally require a relatively very expensive construction. Disasters can also occur due to natural factors and can also occur due to technological failures. Building failure has been defined by RI Law No.2 of 2007 and PP. 29 of 2000. In terms of technicality, building failure occurs when the building lacks / does not have the elements of rigidity, strength, stability, and security, as required in the regulations I provisions that apply to the building. Failure in this case, can be divided into, minor failure, moderate failure and severe failure. Failure can be initiated from failure at the investigation / survey, design / design, construction (implementation) and maintenance stages. In order to determine failure, a benchmark can be used that all buildings must be planned, built, maintained in accordance with national and local regulations as well as various standards of the construction services association. In addition, specifically for designing a foundation, it must be adjusted to the results of soil investigations in the field.

Keywords: Disaster, Soft Soil, Foundation Failure. 


\section{Pendahuluan}

Menurut Asian Disaster Reduction Center (2003), bencana adalah suatu gangguan serius terhadap masyarakat yang menimbulkan kerugian secara meluas dan dirasakan baik oleh masyarakat, berbagai material dan lingkungan (alam) dimana dampak yang ditimbulkan melebihi kemampuan manusia guna mengatasinya dengan sumber daya yang ada.

Menurut Parker (1992), bencana ialah sebuah kejadian yang tidak biasa terjadi disebabkan oleh alam maupun ulah manusia, termasuk pula di dalamnya merupakan imbas dari kesalahan teknologi yang memicu respon dari masyarakat, komunitas, individu maupun lingkungan untuk memberikan antusiasme yang bersifat luas.

Pengertian bencana didalam kerangka perumusan model sistem pengaturan keselamatan bangunan umum, yakni: Kerusakan /keruntuhan bangunan umum baik karena bencana alam maupun oleh ulah manusia yang mengakibatkan tidak efisiennya investasi untuk bangunan tersebut dan biaya eksploitasi serta pemeliharaan menjadi sangat tinggi. Sebaliknya kegagalan bangunan merupakan bencana bila akibat dari kegagalan tersebut menyebabkan investasi bangunan tidak efisien serta tingginya biaya eksploitasi dan pemeliharaan (Hoesin H, 2016).

Tanah lunak terbentuk karena adanya pelapukan dari batuan, terdiri atas partikel partikel dengan ruang kosong yang berisi air dan udara. Dengan demikian antar partikelnya tidak memiliki ikatan yang kuat. Beberapa permasalahan dari kegagalan bangunan yang timbul mencakup, bangunan dan struktur bangunan apa saja yang gagal berikut lokasi dan kondisi kegagalan serta upaya yang dilakukan, apa saja yang menjadi penyebab utama kegagalan tersebut berdasarkan pengamatan di lokasi, dan upaya upaya atau langkah langkah apa saya yang dilakukan atau diusulkan/ disarankan gunan mengurangi atau mencegah terjadinya kegagalan bangunan di daerah yang mempunyai tanah sulit (Hamid A, 2016).

Apa yang dimaksud dengan kegagalan bangunan telah di kemukakan atau didefinisikan dalam Bab I Pasal 1 ayat 6 Undang Undang Republik Indonesia (UU RI) Nomor 18 Tahun 1999 Tentang Jasa Konstruksi, dan disempurnakan pada UU No.2 Tahun 2017, bahwa "Kegagalan bangunan adalah suatu keadaan keruntuhan bangunan dan/ atau tidak berfungsinya bangunan setelah penyerahan akhir hasil Jasa Konstruksi" dan dalam Bab V Pasal 34 Peraturan Pemerintah (PP) Nomor 29 Tahun 2000 tentang Penyelenggaraan Jasa Konstruksi yang berbunyi : "Kegagalan Bangunan merupakan keadaan bangunan yang tidak berfungsi, baik secara keseluruhan maupun sebagian dari segi teknis, manfaat, keselamatan dan kesehatan kerja, dan atau keselamatan umum sebagai akibat kesalahan Penyedia Jasa dan atau Pengguna Jasa setelah penyerahan akhir pekerjaan konstruksi”. Intinya kegagalan bangunan, dari definisi menurut UU dan PP diatas, dapat ditinjau dari kondisi fungsi, teknis, keselamatan pengguna dan keselamatan umum, baik sebagian maupun keseluruhan bangunan tesebut setelah selesai tahap konstruksi dan telah diserahkan pada pemilik bangunan.

Dilihat dari segi ketekniksipilan, Kegagalan bangunan terjadi apabila bangunan tersebut kurang/ tidak memiliki unsur-unsur kekakuan, kekuatan, stabilitas, dan keamanan, sebagaimana yang dipersyaratkan dalam peraturan/ketentuan yang berlaku terhadap

bangunan tersebut (Rahardjo, 1985) . Kegagalan dalam hal ini, dapat dibagi atas, Kegagalan 
ringan, kegagalan sedang dan kegagalan berat. Kegagalan dapat diawali dari kegagalan pada tahap penyelidikan/ survey, perancangan/ disain, konstruksi (pelaksanaan) dan tahap perawatan (Maintenance).

Kegagalan dapat saja terjadi disebabkan dari hal hal yang bersifat nonteknis, seperti kurangnya komunikasi serta ketidak harmonisan para pihak yang terlibat dalam kegiatan proyek bangunan tersebut sejak perancangan sampai pembangunan/ konstruksi. Selain itu bangunan yang sepertinya kokoh di tanah sulit, pada saat terjadi bencana alam seperti gempa, bangunan tersebut runtuh dan ambruk ke dalam atau masuk kedalam tanah.

Guna menentukan kegagalan dapat dipakai tolak ukur bahwa semua bangunan harus direncanakan, di bangun, di pelihara mengikuti peraturan nasional dan peraturan daerah serta berbagai standar dari asosiasi asosiasi jasa konstruksi. Selain itu khusus untuk mendisain sebuah pondasi harus menyesuaikan dengan hasil penyelidikan tanah di lapangan.

Selanjutnya dalam konteks permasalahan ini akan dibahas mengenai kegagalan bangunan dari sudut pandang pekerjaan sipil/konstruksi khusunya pondasi

\section{Literature Review}

Literature reviuw dalam penulisan ini berupa hasil kajian yang telah dilakukan terkait state of the art teori terkini, kasus-kasus bencana akibat kegagalan struktur pondasi, penyebab, dampak dan proses penanganan bencana.

\section{A. State of The Art}

Akibat yang ditimbulkan bencana bisa berbeda-beda, dalam hal ini bencana dapat dikelompokkan menjadi beberapa macam diantaranya:

Bencana yang akibatnya dapat mengurangi atau mengganggu kestabilan / kenyamanan pemakai. Bencana semacam ini tidak sampai membahayakan jiwa, tetapi dapat menimbulkan kerugian, misalnya berupa biaya pemeliharaan menjadi lebih tinggi, bisa juga berakibat bangunan tidak berfungsi sebagaimana yang direncanakan, misalnya reservoir atau menara air yang tidak dapat diisi penuh. Ada juga yang akibatnya mengganggu pandangan dengan perkataan lain segi-segi estetikanya tidak tidak seperti yang diharapkan.

Definisi Bencana Undang-undang Nomor 24 Tahun 2007 Tentang Penanggulangan Bencana menyebutkan definisi bencana sebagai berikut: Bencana adalah peristiwa atau rangkaian peristiwa yang mengancam dan mengganggu kehidupan dan penghidupan masyarakat yang disebabkan, baik oleh faktor alam dan/atau faktor nonalam maupun faktor manusia sehingga mengakibatkan timbulnya korban jiwa manusia, kerusakan lingkungan, kerugian harta benda, dan dampak psikologis .

Menurut Coburn, A. W. dkk. 1994. Di dalam UNDP mengemukakan bahwa : Bencana adalah Satu kejadian atau serangkaian kejadian yang member meningkatkan jumlah korban dan atau kerusakan, kerugian harta benda, infrastruktur, pelayanan-pelayanan penting atau sarana kehidupan pada satu skala yang berada di luar kapasitas norma (Coburn, 1994).

Sedangkan Haryanto S.H (2001 : 35) Mengemukakan bahwa: Bencana adalah Terjadinya kerusakan pada pola pola kehidupan normal, bersipat merugikan kehidupan manusia, struktur sosial serta munculnya kebutuhan masyarakat. 
Menurut Undang-undang No. 24 Tahun 2007, bencana adalah peristiwa atau rangkaian peristiwa yang mengancam dan mengganggu kehidupan dan penghidupan masyarakat yang disebabkan, baik oleh faktor alam atau faktor non alam maupun faktor manusia sehingga mengakibatkan timbulnya korban jiwa manusia, kerusakan lingkungan, kerugian harta benda, dan dampak psikologis.

Jenis-jenis Bencana menurut Undang-undang Nomor 24 Tahun 2007 tentang penanggulangan bencana, yaitu:

a. Bencana alam adalah bencana yang diakibatkan oleh peristiwa atau serangkaian peristiwa yang disebabkan oleh alam antara lain berupa gempa bumi, tsunami, gunung meletus, banjir, kekeringan, angin topan, dan tanah longsor;

b. Bencana non alam adalah bencana yang diakibatkan oleh peristiwa atau rangkaian peristiwa non alam antara lain berupa gagal teknologi,gagal modernisasi. dan wabah penyakit;

c. Bencana sosial adalah bencana yang diakibatkan oleh peristiwa atau rangkaian peristiwa yang disebabkan oleh manusia yang meliputi konflik sosial antar kelompok atau antar komunitas masyarakat.

d. Kegagalan Teknologi adalah semua kejadian bencana yang diakibatkan oleh kesalahan desain, pengoprasian, kelalaian dan kesengajaan, manusia dalam penggunaan teknologi dan atau insdustri yang menyebabkan pencemaran, kerusakan bangunan, korban jiwa, dan kerusakan lainnya.

Bencana yang akibatnya, sebagian atau keseluruh bangunan tidak dapat dipakai dalam jangka waktu yang terbatas. Kerugian pada kegagalan/bencana bangunan semacam ini umumnya akan lebih besar daripada kerugian pada kegagalan macam pertama, hanya bangunannya masih dapat diperbaiki dan dipakai lagi walaupun mungkin saja tidak dapat dimanfaatkan sepenuhnya seperti rencana semula .

Bencana yang berakibat sebagian atau seluruh gedung/bangunan runtuh. Jelas disini kerugian yang ditimbulkan besar sekali dan kemungkinan terdapat korban jiwa.

Kegagalan bangunan (building failure) diartikan sebagai kegagalan yang terjadi pada satu atau beberapa unsur bangunan sehingga elemen/unsur bangunan tersebut menjadi tidak/kurang berfungsi/rusak yang menyebabkan kerugian biaya/harta benda serta dapat mengancam keselamatan pemakai bangunan. Ditinjau dari segi kegagalan (fungsi unsur bangunan) yang terjadi pada suatu bangunan, maka kegagalan (fungsi unsur bangunan) yang terjadi pada suatu bangunan, maka dapat dikelompokkan kedalam pembagian sebagai berikut:

a. Kegagalan struktur (Struktural failure),

b. Kegagalan instalasi (Installation failure),

c. Kegagalan arsitektur (Arsitectural failure)

Dapat pula dikombinasikan dari 2 atau lebih unsur jenis kegagalan tersebut.

Ketiga jenis kegagalan bangunan tersebut diatas dapat secara langsung maupun tidak langsung menimbulkan atau ditimbulkan oleh berbagai kejadian seperti uraian berikut: Struktural Failure, Instaltion Failure dan Architectural Failure. 
Structural Failure

Yang termasuk Struktural failure adalah sebagai berikut:

1) Kerusakan Fondasi:

(1). Kondisi tak stabil; (2). Kerusakan kondisi tanah (kadar air tanah, perembesan air, air permukaan, air tanah, tanah miring, pasang surut,banjir); (3). Gerakan-gerakan tanah (akibat kesalahan geologis, vibrasi, unequal settlement: akar tanaman, retak-retak tanah liat, endapan mineral), (4). Reaksi kimia.

2) Kerusakan Lantai:

(1) Perembean air, (2). Reaksi kimia, (3). Effluorescence atau kristalisasi garam-garam tanah dekat permukaan. (4). Retak-retak didalam akibat gerakan tanah.

3) Kerusakan Atap:

(1). defective roof covering. (2). Defective metal roof covering. (3). Retak-retak/surface shringnkeage creacks. (4). chemical attack

4) Kerusakan Dinding:

(1). Retak-retak dinding, (2). Pengkerutan/shrinkage. (3). Jamur/effuorescence. (4). Spalling/Lepas-lepas beton. (5). Dampness. (6). Permukaan dinding berparutparut/scarred surface.

5) Kerusakan Rangka Baja:

(1). Kerusakan kerangka baja yang tidak ditopang (spacel) dengan baik, terkena tekanan berat (misal Angin keras)

6) Kebakaran Dalam Bangunan.

karena:(1) Fire-sprinkler tidak berfungsi, (2) Konsleting listrik

Elemen-elemen struktur terbagi menjadi dua kelas besar, sesuai dengan letak dan tugasnya. Bagian pertama merupakan elemen struktur yang berada di bawah tanah, yang biasa disebut pondasi. Sedangkan bagian yang lain adalah elemen-elemen struktur yang berada di atas tanah.

Pondasi merupakan bagian dari elemen bangunan yang berfungsi meletakkan dan meneruskan seluruh beban dari bangunan ke dasar tanah yang keras sehingga kuat mengimbangi dan mendukung (merespon) serta dapat menjamin kestabilan bangunan, paling tidak terhadap beratnya sendiri, beban yang bekerja serta beban gempa (Noorlaelasari, 2010).

Untuk menjaga kestabilan pondasi dan memperoleh daya dukung tanah yang besar, dasar pondasi harus diletakkan lebih dari $50 \mathrm{~cm}$ di dalam permukaan tanah sampai mencapai lapisan yang keras. Lebar galian tanah pondasi dibuat secukupnya asal bisa untuk memasang pondasi, karena tanah yang sudah terusik akan berubah sifat maupun kekuatannya.

Secara garis besar kondisi tanah dikelompokkan menjadi 2 tipe :

a. Jenis tanah bersifat "Stabil"

b. Jenis tanah bersifat "Labil" atau tidak stabil

Tanah dikatakan stabil apabila tanah tersebut tidak mengalami perubahan dalam musim kemarau maupun musim penghujan. Maksud tidak mengalami perubahan ini adalah tidak terjadinya gerakan-gerakan tanah ke atas, ke bawah dan ke samping. 
Dalam kaca mata profesi Teknik sipil fungsi utama bangunan adalah memikul bebanbeban dan pengaruh lingkungan luar. Jadi bangunan yang gagal adalah jika tidak mampu memikul beban atau rusak akibat pengaruh lingkungan luar.

Konsekuensi dari kegagalan struktur bangunan selain rusaknya bangunan tetapi juga dapat menyebabkan kecelakaan yang timbulnya korban jiwa, cedera dan lainnya yang disebabkan oleh jatuhnya material. Kegagalan bangunan dapat berupa bagian dari bangunan yang retak, misalnya struktur beton bertulang yang suatu waktu bisa saja mengalami keretakan yang serius atau lebih besar dan menyebabkan robohnya suatu bangunan. Misalnya hal yang buruk akan terjadi yang mengakibatkan korban jiwa akbat sebuah bangunan tinggi mengalami kegagalan struktur.

Selain itu, kerusakan propertis bekas keruntuhan bangunan perlu menghabiskan waktu untuk membersihkan, memperbaiki dan memerlukan biaya untuk mengembalikan seperti normalnya.

Cacat konstruksi merupakan suatu kondisi penyimpangan atau ketidak sempurnaan hasil dan atau proses pekerjaan konstruksi yang masih dalam batas toleransi. Artinya belum atau tidak membahayakan konstruksi secara keseluruhan. Kegagalan konstruksi adalah suatu kondisi penyimpangan, kesalahan dan atau kerusakan hasil pekerjaan konstruksi yang dapat mengakibatkan keruntuhan konstruksi (Sumardjito, 2011).

\section{B. Kasus kasus bencana terkait}

Beberapa kasus bencana terkait dengan kegagalan pondasi pada bangunan sipil antara lain :

Konstruksi lepas pantai (offshore) berbeda di dalam perencanaanya dengan kontruksi di daratan (onshore) dan konstruksi di dekat pantai (near shore) dan merupakan sebuah anjungan besar yang menyediakan fasilitas seperti pelabuhan. Pembangunan pelabuhan memegang peranan penting seperti administrative, perkembangan, industrial dan komersial. Pelabuhan mencakup struktur dermaga yang merupakan fasilitas tempat kapal keluar masuk dan transfer muatan yang umumnya terletak pada tepi laut, sungai, maupun danau. Struktur pada dermaga didukung oleh pondasi yang meneruskan beban yang dipikul ke dalam lapisan tanah. Tanah harus mampu memikul beban tanpa mengalami kegagalan. Pondasi yang umumnya digunakan adalah pondasi tiang. Pada tahap perencanaan, daya dukung pondasi perlu diperhatikan secara saksama karena kegagalan konstruksi dapat terjadi apabila pondasi tidak mampu menahan beban yang dipikul. Kegagalan yang terjadi pada tiang pancang konstruksi dermaga pada salah satu kawasan pulau di Indonesia merupakan suatu kasus nyata yang menimbulkan permasalahan pada struktur dermaga dan trestle. Kegagalan terjadi pada podasi tiang pipa baja konstruksi dermaga yang disebabkan karena kesalahan dalam mendisain struktur dermaga dan trestle, yaitu salah dalam menentukan posisi pelabuhan yang terletak di muara yang yang membawa endapan sehingga menurunkan kapasitas pondasi, ujung tiang yang tidak bersandar pada tanah keras, tidak mempertimbangkan beban siklik dan efek Scouring (Ivana, 2018).

Di lain kasus kegagalan pondasi terjadi pada bangunan ruko tiga lantai, sehingga menyebabkan bangunan mengalami keruntuhan, Sebagai tindak lanjut kondisi tersebut, perlu dilakukan penelitian untuk mengevaluasi kegagalan yang terjadi dan memberikan alternative solusinya (Marzuki, 2016). 


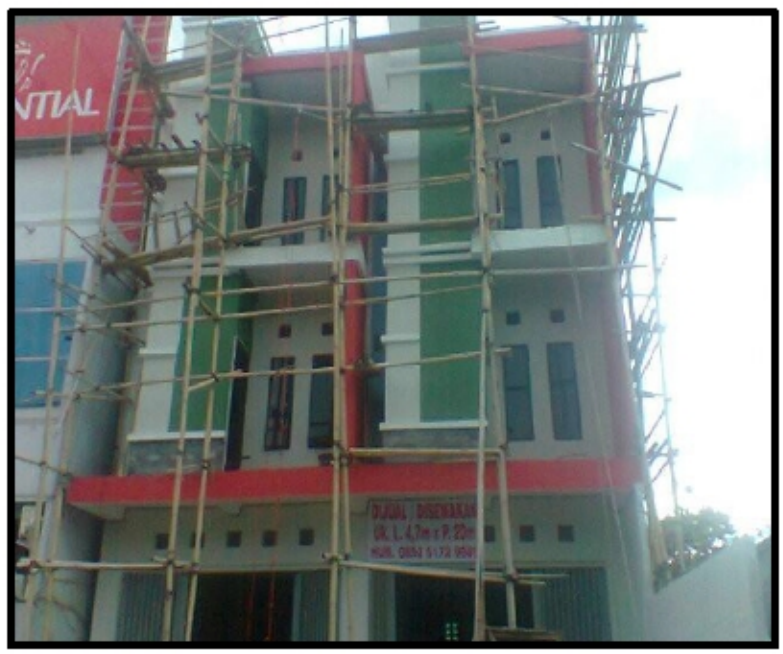

a.Kondisi existing bangunan ruko lantai tiga
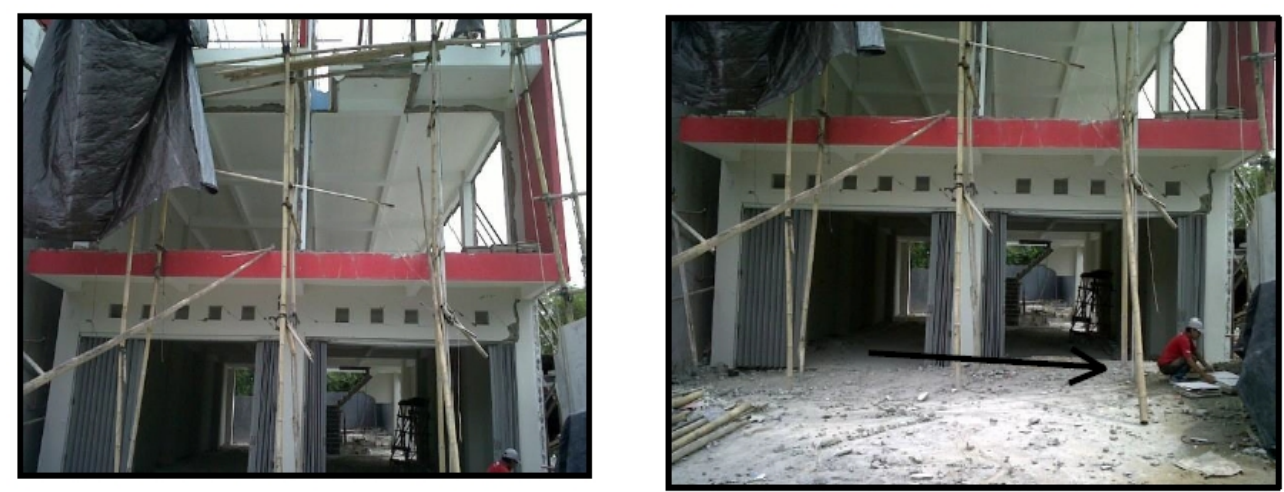

b.Bentuk kerusakan pada bangunan atas.
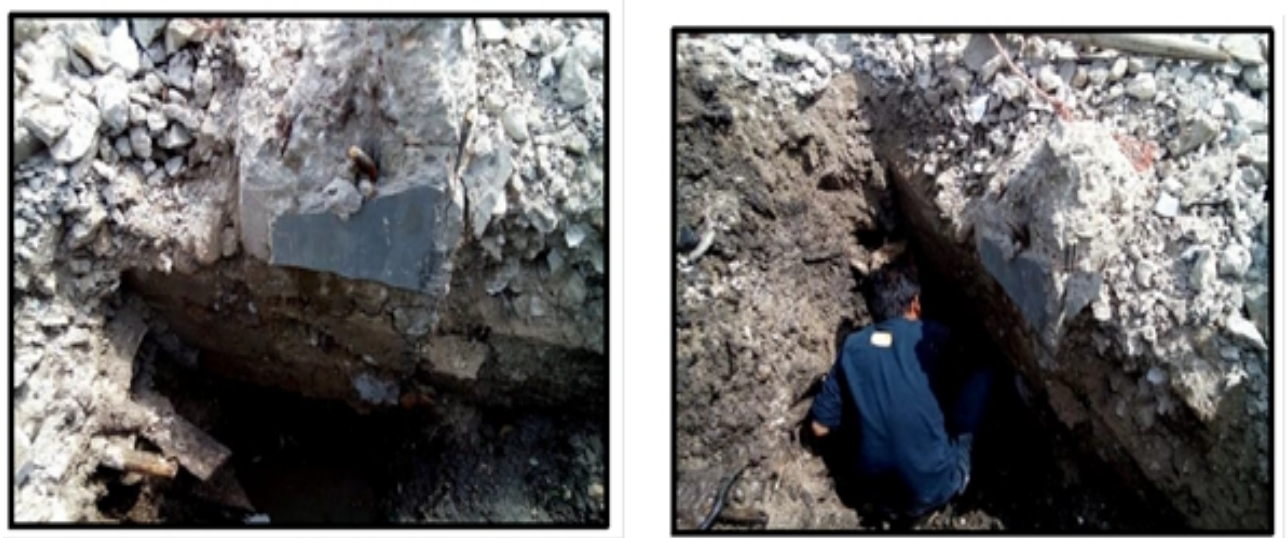

c. Kerusakan pada struktur bawah bangunan.

Gambar 1. Kegagalan struktur bangunan Ruko Lantai 3 [16]

Dari hasil penyelidikan kondisi eksisting di lapangan kemungkinan penyebab terjadinya kegagalan bangunan adalah : 
a. Pada struktur bangunan bawah tidak terdapt sloof, sehingga apabila terjadi penurunan seketika (Immediate Settlement) yang tidak seragam mengakibatkan plat pondasi mudah patah.

b. Terjadi eksentrisitas neut terhadap titik pusat pondasi sehingga terjadi tambahan momen pada system pondasi

c. Kedalaman tiang galam pada pondasi hanya sedalam $7 \mathrm{M}$ (tujuh meter) masih belum mencapai syarat safety factor sehingga bangunan sangat berpotensi mengalami kegagalan (failure)

d. Tidak adanya penyelidikan tanah di lokasi pembangunan sehingga tidak ada dasar perhitungan terhadap disain pondasi yang digunakan

Beberapa alternatif solusi redisain adalah melakukan penambahan kedalaman tiang, penambahan sloof dan penambahan jalur pondasi arah melintang.

Sebuah kasus yang berhubungan dengan kegagalan struktur jembatan rangka baja kelas B melintang sungai Bahalang di daerah Ampah Kalimantan Tengah sebagai penghubung jalan yang dibangun untuk angkutan batu bara, memegang peranan penting di dalam menunjang laju pertumbuhan perekonomian masyarakat wilayah setempat. Usaha pembangunan jembatan mendapat kendala yaitu kerusakan pada abutmen yang terletak di bagian timur jembatan. Terjadi rotasi sebesar 30 sehingga bagian belakang abutmen mengalami penurunan sedalam 2 meter dan bergeser dari letak semula menuju kearah sungai sejauh 1 meter.

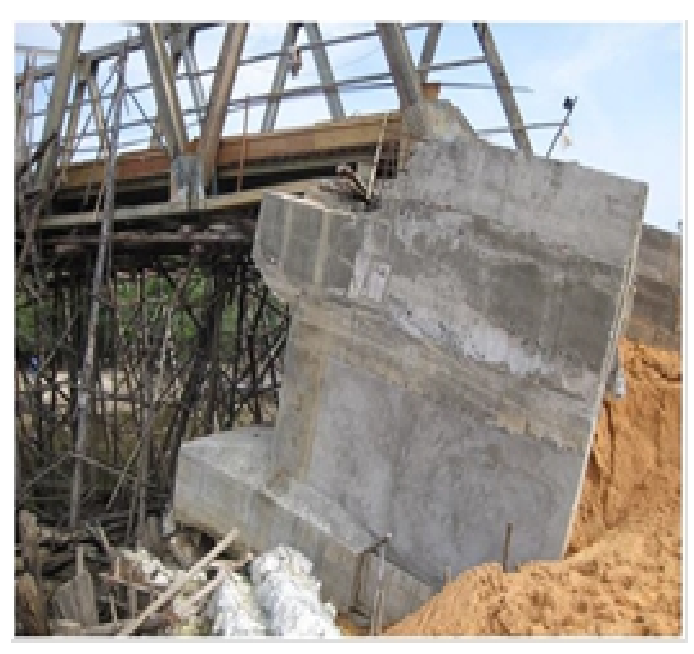

a.Keadaan Abudmen

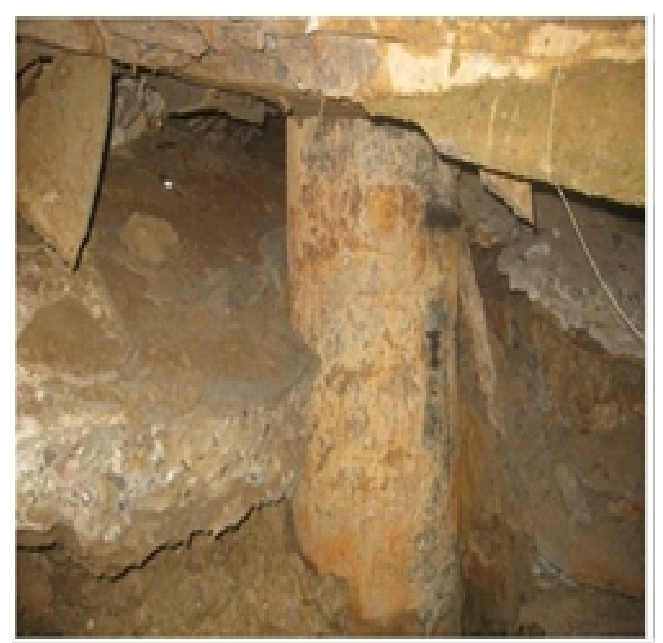

b. Pondasi tiang abudmen

Pada Gambar 2b, diperkirakan bahwa tiang di tumpukan bawah bagian belakang abutmen yang turun telah tertekuk atau menjauh dari struktur dan tidak memberikan dukungan beban. 


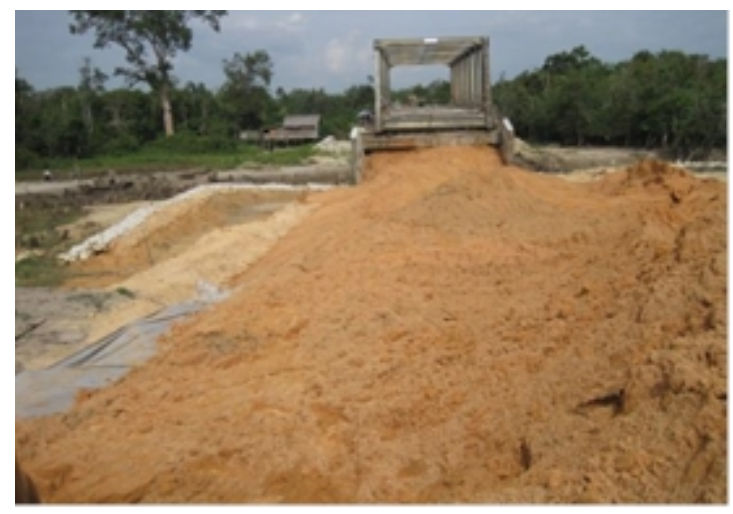

c. Pekerjaan timbunan di belakang abutmen

Gambar 2. Kegagalan struktur pondasi abutmen

Kegagalan terjadi setelah pengurugan tanah timbunan di daerah belakang abutmen bagian sebelah timur. Timbunan terdiri dari bahan pasir yang ditempatkan secara cepat dan langsung dari bak truk, kemudian diratakan dengan excavator seperti pada gambar 2c. Kegiatan penyelidikan tanah memegang peranan penting khususnya dalam pekerjaan perencanaan konstruksi jembatan. Sebaiknya perencana berhati hati dalam melakukan perhitungan yaitu dengan memasukkan banyak pertimbangan dari beberapa aspek geoteknik sehingga menghasilkan perencanaan yang lebih akurat dan aman (Hidayat, 2011).

Runtuhnya apartment di Shanghai, Cina merupakan salah satu bencana yang terjadi akibat kegagalan struktur, disinyalir karena kecerobohan pekerja bangunan yang membuang tanah bekas galian sembarangan. Ketika membangun area parkir di bawah Gedung, para pekerja justru membuang tanah bekas galiannya ke dekat areal pembunagan sampah. Akibat penumpukan terjadi, tepian dinding sungai di dekatnya menjadi runtuh dan menyebabkan air sungai meresap ke bagian basement. Akhirnya basemen tersebut jadi kebanjiran dan menyebabkan pondasi menjadi runtuh, Gedung tersebut ambruk ke salah satu sisi secara utuh.
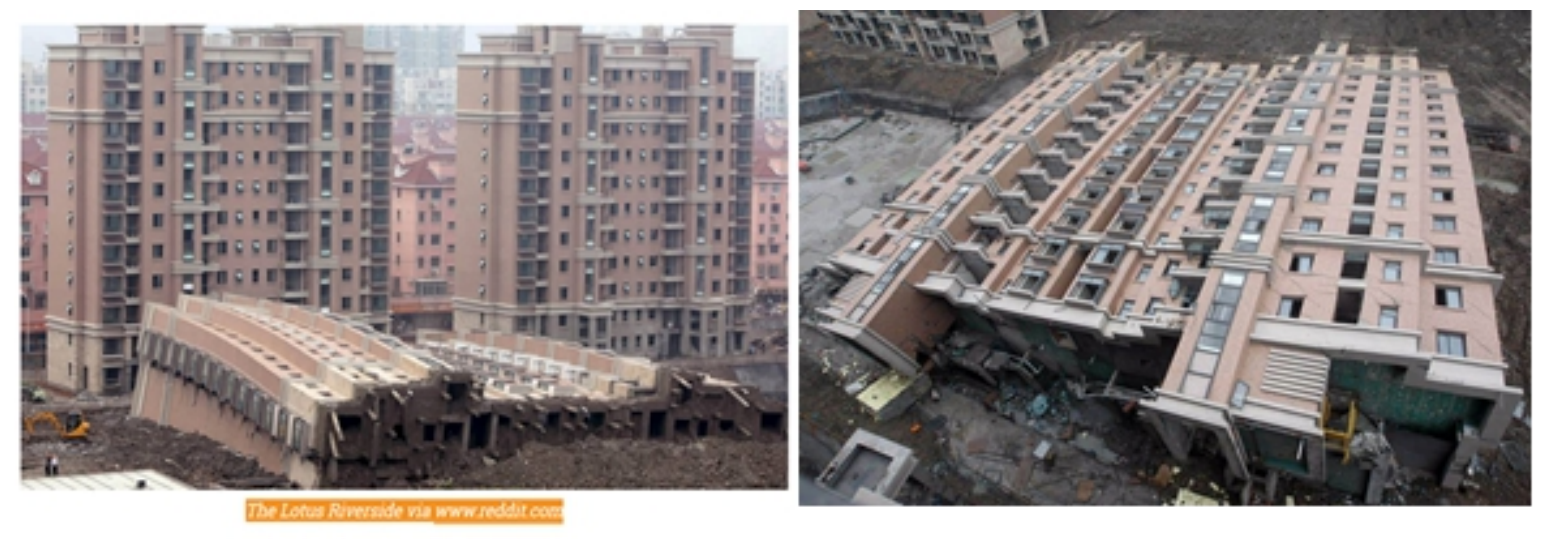

Gambar 3. Kegagalan konstruksi bangunan

Jembatan penyeberangan orang (JPO) di kawasan Pasar Minggu, Jakarta Selatan, ambruk pada tahun 2016. Jembatan penyebrangan orang di Pasar minggu ini dibangun oleh Dinas Perhubungan ambruk setelah diterpa hujan lebat menelan 10 korban. Beberapa 
analisa penyebab kejadian tersebut diantaranya pemasangan papan reklame yang tidak sesuai dengan prosedur. Pemasangan papan reklame pada bagian atas jembatan atau pada railing jembatan, pada saat angin terhambat di bagian reklame JPO roboh karena tak mampu menahan dorongan angin yang menghambat tersebut.
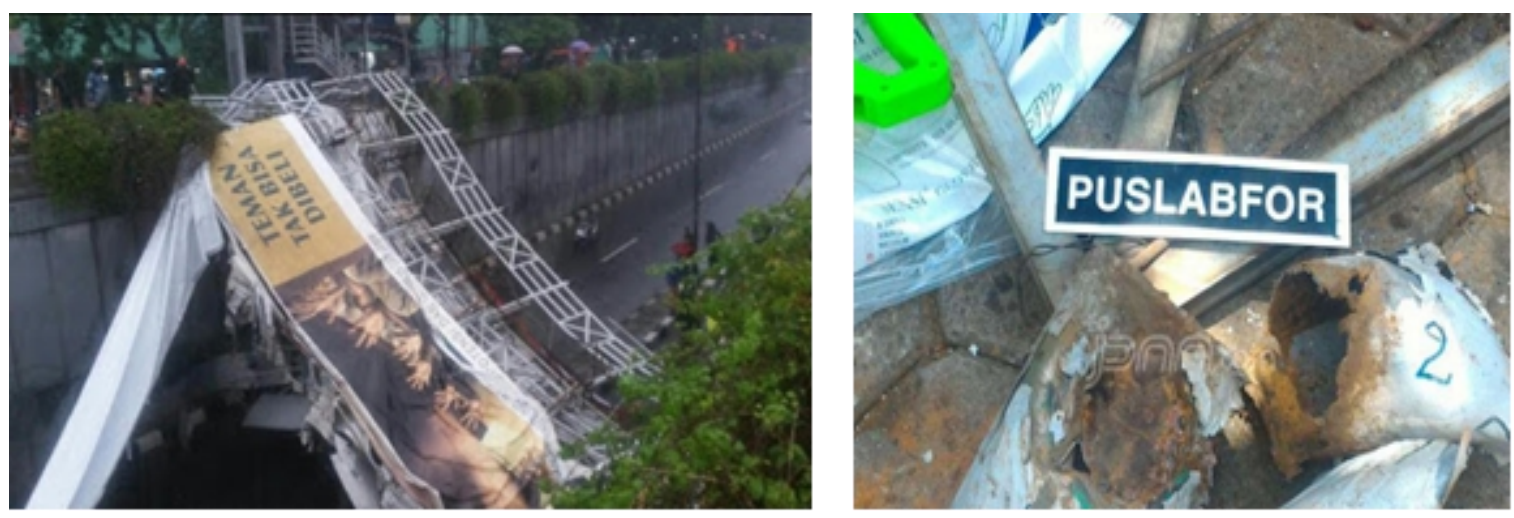

Gambar 3. Kondisi Jembatan penyebrangan orang (JPO)

Salah satu kasus pasca gempa Sumatera Barat 2009, banyak bangunan yang runtuh, dan rusak ringan sampai berat yang membutuhkan perbaikan. Beberapa penyebab kerusakan atau keruntuhan yang terjadi pada bangunan diantaranya, detailing tulangan yang tidak mengikuti standart yang ada termasuk sambungan balok kolom (Zaidir, 2018).
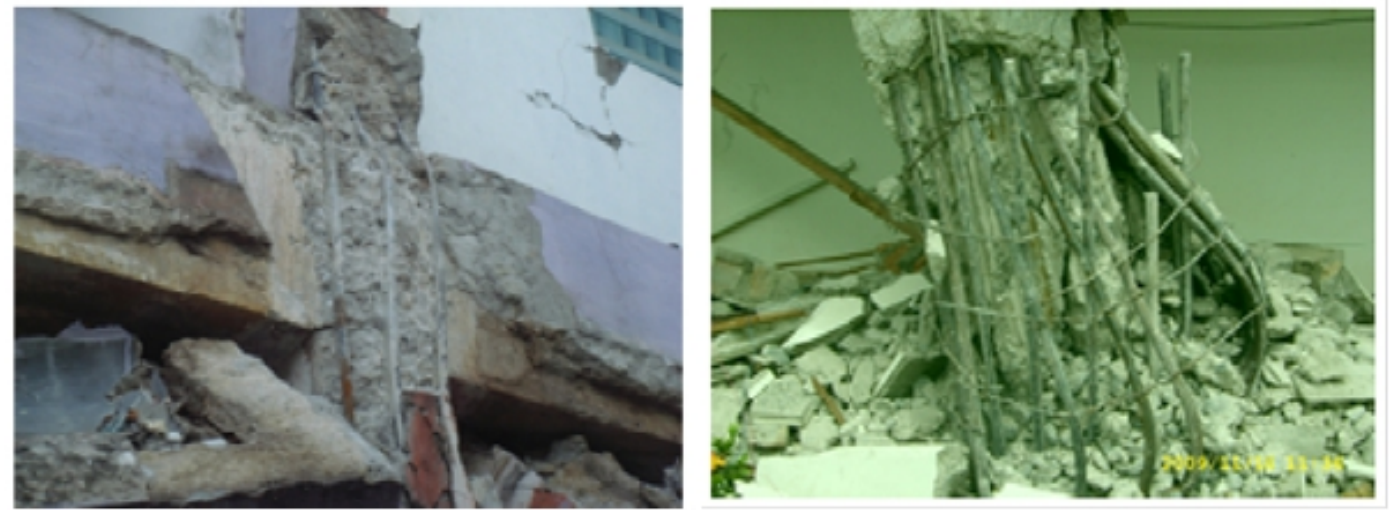

Gambar 4. Detailing penulangan yang tidak sesuai standart

Kegagalan pada pondasi, terutama pada sambungan kolom pondasi (Soil structure interaction, efek liquifaksi) 


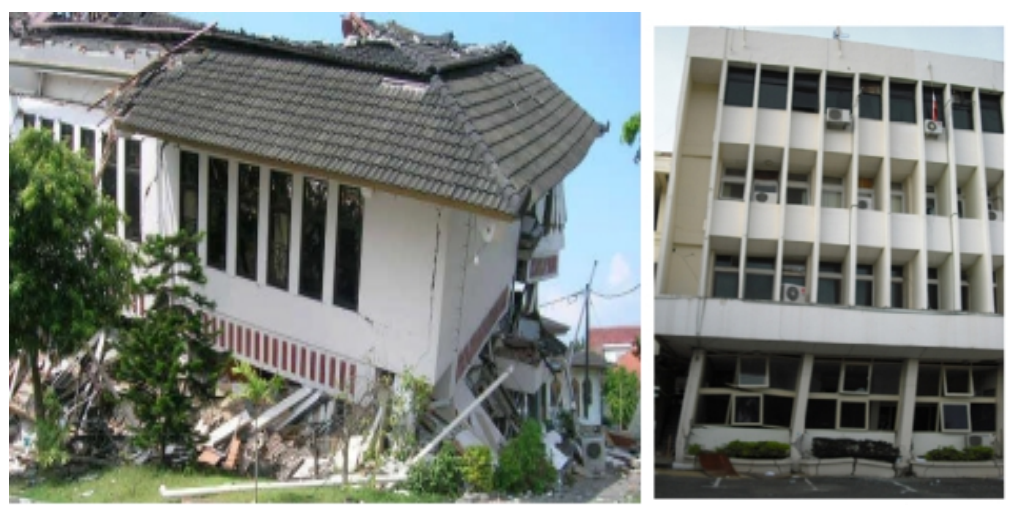

Gambar 5. Kegagalan pondasi akibat efek liquifaksi

(Zaidir, 2018)

Metode perbaikan dan perkuatan bangunan pasca gempa dapat dilakukan dengan melakukan survey lapangan untuk menentukan jenis kerusakan bangunan maupun komponen/ bagian bagian bangunan dan mutu bahan bangunan yang digunakan. Melakukan analisis struktur berdasarkan standart gempa terbaru untuk mengetahui penyebab suatu elemen bangunan rusak, akibat gempa (Zaidir, 2018)

\section{Metode Penelitian}

Metode yang digunakan dalam penulisan ini adalah metode penelitian deskriptif. Metode yang digunakan untuk pengumpulan data adalah metode studi pustaka yang terdiri atas pencarian data dan informasi melalui dokumen-dokumen pendukung berupa data dari buku, jurnal ilmiah, dan dokumen elektronik dari internet. Adapun tahapan dalam penulisan diantaranya perumusan masalah untuk kemudian menjadi gagasan, pengumpulan data dan fakta terkait, verifikasi data dan fakta, analisa konseptual, perumusan hasil gagasan dan kesimpulan serta rekomendasi terkait penanganan masalah.

\section{Hasil dan Pembahasan}

Dari hasil studi literatur yang ternyata tidaklah mudah untuk mendapatkan data bangunan yang mengalami kegagalan, Sebagian besar bangunan bangunan tersebut berlokasi atau terletakan di atas tanah lunak, ada dua struktur bangunan yang cukup menonjol pada hampir setiap kegagalan, yaitu, pondasi bangunan yang mengalami penurunan (kasus dermaga, jembatan dan bangunan rumah, toko) dan balok/ kolom, dalam hal ini terutama daerah hubungan antara balok dan kolom. 
Penyebab utama kegagalan sebagian besar di perkirakan adalah kualitas bahan dan kuantitas pekerjaan (quality control) yang kurang baik. Perlu di cermati lagi dalam pemilihan bentuk pondasi yang akan digunakan, ada beberapa hal yang harus dipertimbangkan, antara lain :

a. Keadaan tanah pondasi

b. Batasan Batasan akibat konstruksi di atsnya

c. Batasan Batasan dari sekelilingnya

d. Waktu dan biaya pekerjaan

Bila keadaan tersebut ikut di pertimbangkan, maka kita dapat memilih jenis jenis pondasinya yaitu sebagai berikut:

a. Bila tanah pendukung pondasi terletak pada permukaan tanah 1 meter di bawah permukaan tanah, dalam hal ini pondasinya adalah pondasi dangkal

b. Bila tanah pendukung pondasi terletak pada permukaan tanah, dalam hal ini pondasinya adalah pondasi telapak

c. Bila tanah pendukung terletak pada kedalaman sekitar $10 \mathrm{M}$ di bawah permukaan tanah, dalam hal ini di gunakan pondasi tiang apung (floating pile foundation)

d. Bila tanah pendukung pondasi terletak pada kedalaman sekitar 20 meter di bawah permukaan tanah, dalam hal ini tergantung dari penurunan yang diizinkan, dapat di pakai jenis pondasi tiang pancang.

e. Bila tanah pendukung pondasi terletak pada kedalaman sekitar 30 meter di bawah permukaan tanah biasanya di pakai beton koison terbuka, tiang baja, atau tiang baja, atau tiang yang di cor di tempat

f. Bila tanah pendukung terletak pada kedalaman lebih dari 40 meter di permukaan tanah dalam hal ini yang paling banyak digunakan adalah tiang baja dan tiang beton yang dicor di tempat.

Pondasi yang berada di tanah ekspansif harus dilakukan modifikasi atau perbaikan tanah baik secara fisik maupun secara kimia (Hardiyatmo, 2010).

Disaster manajement merupakan serangkaian upaya yang meliputi penetapan kebijakan pembangunan yang berisiko timbulnya bencana, kegiatan pencegahan bencana, tanggap darurat, rehabilitasi dan rekonstruksi (Ariantoni dkk, 2009).

Pada saat pemulihan (Recovery) yang merupakan proses pemulihan darurat kondisi masyarakat yang terkena bencana, dengan memfungsikan kembali prasarana dan sarana pada keadaan semula. Rehabilitasi merupakan upaya langkah yang diambil setelah kejadian bencana untu membantu masyarakat yang tertimpa musibah ataupun bencana akibat kegagaln struktur. Rekonstruksi yaitu program jangka menengah dan jangka panjang guna perbaikan fisik bangunan baik itu membangun baru atau melakukan retrofitting.

Bencana gempa dapat menyebabkan banyak bangunan rusak dan juga dapat menyebabkan keruntuhan. Setelah terjadi gempa, banyak bangunan yang rusak tersebut dirubuhkan atas saran dari pakar, konsultan maupun pihak pemangku kepentingan, sementara sebenarnya bangunan tersebut masih bisa diperbaiki dan dilakukan perkuatan sehingga bangunan tersebut dapat digunakan kembali (Febrin Anas I, et.al, 2014). 
Memberi saran untuk merubuhkan bangunan yang rusak setelah gempa merupakan keputusan yang mudah, tetapi tidak didukung oleh data yang memadai. Sampai saat ini Indonesia belum punya standar dalam melakukan asesmen kerusakan serta metoda perbaikan dan perkuatan bangunan yang rusak pasca gempa. Keuntungan utama melakukan perbaikan dan perkuatan bangunan yang rusak pasca gempa akan dapat menghemat waktu dan biaya (Febrin Anas I, 2011).

\section{Simpulan}

Sesuatu kebiasaan yang tidak terpuji tentang masalah kegagalan konstruksi di suatu proyek, pihak-pihak yang terkait selalu ada cara untuk memilih langkah-langkah mengamankan dan menyelamatkan orang-orangnya yang terlibat dari pada mengamankan atau menyelesaikan masalah-masalah itu sendiri. Tidak jarang kondisi alamlah yang dikambing hitamkan untuk menyelamatkan kecerobohan dan kelalaian manusia-manusia yang seharusnya bertanggung jawab dalam kegagalan konstruksi tersebut.

\section{Daftar Pustaka}

Asian Disaster Reduction. 2003. Definisi bencana.

Parker (1972) Pencegahan dan Manajemen Bencana. Retrieved from http://social-studies17.blogspot.com/2012/11/recognize-pencegahan-bencanadan.html Diakses tanggal 15 April 2019

Hoesin H. (n.d) Bencana adalah kegagalan bangunan (Building Failure),

Blog Bukik Ranah Ilmu, Posted By Lizenhs, diakses tanggal 16 April 2019, https://izenhs.wordpress.com/2016/10/04/bencana-adalah-kegagalanbangunan-building-failure/ 2016

Hamid A, (2016) Kegagalan bangunan pada tanah lunak, Jurnal Teknik Sipil Universitas Tanjung Pura Pontianak

Republik Indonesia. Undang-Undang No. 2 Tahun 2017 tentang Jasa Konstruksi. Lembaran Negara RI Tahun 2017. Sekretariat Negara. Jakarta. 2017

Republik Indonesia. 2000. Peraturan Pemerintah No. 29 Tahun 2000 tentang Penyelenggaraan Jasa Konstruksi. Lembaran Negara RI Tahun 2000. Sekretariat Negara. Jakarta.

P. Rahardjo., Sosrowinarso., dan Zanussi.(1985), serta LPJK (2007), Kegagalan bangunan

Undang-Undang Republik Indonesia No. 24 tahun 2007 tentang Penanggulangan Bencana, h. 2.

Coburn, A. W. dkk. (1994). Mitigasi Bencana II. Program Pelatihan Manajemen Bencana. Cambridge-United Kingdom: DHA-UNDP. Direktorat Geologi, Bandung. 
Haryanto, S.H Pengertian Bencana 2001 : 35

Noorlaelasari, Y, Bahan ajar pondasi dangkal, Teknik Sipil Politeknik Bandung 2010, Bandung

Bahan ajar Teknik pondasi dangkal

Sumardjito, Bahan Ajar Cacat dan kegagalan konstruksi 2011

Ivana Natsya, C. A. M. (2018). Analisis Kegagalan Tiang Pancang pada Konstruksi Dermaga dengan Program A Pile Offshore, L Pile, dan GRLWEAP. Jurnal Mitra Teknik Sipil, 1, 177.

Marzuki A, A. (2016). Evaluasi Kegagalan Pondasi pada Gedung bertingkat (Studi Kasus : Proyek Pembangunan Ruko 3 Lantai - Banua Anyar Banjarmasin). Prosiding Seminar Nasional Geoteknik 2016.

Hidayat, G. (2011). Studi Kasus Analisis Kerusakan Abutmen Jembatan Sungai Bahalang Kalimantan Tengah. Jurnal Teknologi Berkelanjutan, Vol. 1, 10.

Dunia Teknik Sipil 2017, Kegagalan Konstruksi di lihat dari sudut pandang etika profesi diakses tanggal 15 April 2019

Zaidir dkk. (2018), Perbaikan dan perkuatan bangunan pasca gempa sumatera Barat Tahun 2009, Prosiding PIT Ke-5 Riset Kebencanaan IABI Universitas Andalas 2018

Hardiyatmo, H. C. (2010). Stabilisasi Tanah Untuk Perkerasan Jalan. Yogyakarta: Gadjah Mada University Press.

Ariantoni, dkk, Modul Pelatihan: Pengintegrasian Pengurangan Resiko Bencana (PRB) Ke dalam Sistem Pendidikan (Jakarta: Pusat Kurikulum Badan Penelitian dan Pengembangan Kementeriam Pendidikan Nasional, 2009), h. 28

Febrin Anas I, et.al, 2014, Retrofitting of Bumiminang Hotel Building in Padang, The 6th Civil Engineering Conference in Asia Region (CECAR6), Jakarta.

Febrin Anas I, Abdul Hakam and Fauzan, 2011, Kerusakan Bangunan Hotel Bumi Minang Akibat Gempa 30 September 2009" Jurnal Teknik Sipil ITB, ISSN 0853-2982, Vol 10 no. 2 pp 119-125. 